\title{
THE STAGES OF USERS' CONCERN WHEN ADOPTING NEW TECHNOLOGY
}

\author{
ELAINE HARRIS \\ KAREL STANZ \\ JANNIE ZAAIMAN \\ THOMAS GROENEWALD \\ Department of Human Resource Management \\ RAU University
}

\begin{abstract}
The aim of this study is to determine whether users move through stages of concern when adopting technology and whether certain demographical characteristics; age, the department the employees operate in and the length of using the innovative technology affects the stage of technology adoption. The sample which were drawn from the oil industry, consisted of 25 Finance employees from Company A and 32 Customer Service Centre and 22 Logistics employees from Company B. In terms of the gathered statistics on the stages of concern, users reached either stages $1 / 2$ (Information/Personal) or 4/5 (Consequences/Collaboration). No statistical significance was found in terms of age, department and length of using the innovative technology.
\end{abstract}

\section{OPSOMMING}

Die doel van hierdie studie was om te bepaal of gebruikers deur verskillende fases van aanvaarding beweeg wannee nuwe tegnologie ingebruik geneem word, en of sekere demografiese eienskappe soos byvoorbeeld ouderdom, die spesifieke afdeling waarin die individu werksaam is asook die duur van die gebruik van die tegnologie, die fase van aanvaarding van nuwe tegnologie affekteer. Die steekgroep het bestaan uit werknermers in die oliebedryf, naamlik 25 Finansiele werknemers van organisasie A, en 32 Kliente Dienssentrum werknemers asook 22 werknemers van die Logistieke Afdeling van organisasie B. Resultate het gewys dat die meerderheid van gebruikers, fase $1 / 2$ of fase $4 / 5$ bereik het. Geen statisties beduidende verband tussen, ouderdom, afdeling en duur van gebruik van nuwe tegnologie is gevind nie.

Within our highly competitive, global business environment, Information and Communication Technology (ICT) has been widely viewed as a silver bullet for achieving competitive advantage. Celebrated anecdotes highlight the key role ICT can play in continuously developing more flexible and innovative products and customer's services. Technology has probably therefore become the most critical enabling resource in bringing about quantum jumps in organisational performance, extending a company's possible future, and enabling the actualisation of a different chosen future. Very often technological innovation makes a life or death difference for an organisation (Veldsman, 2002, p. 184)

Not surprisingly the growing imperative for all businesses to innovate and enhance quality while containing costs has prompted massive expenditures on ICT. Yet companies are not fully realising the foreseen benefits as highlighted in a survey conducted by Sauer and Yetton (1998) between 1995 - 1997 covering over 3000 projects. Between 25 to 75 percent of technology innovations failed to achieve their goals. The study conducted by Johnson in 1995 as quoted by Carlopio $(1998$, p. 2$)$ suggests that $31 \%$ of technology projects were cancelled before completion, 53 percent had overrun their costs and budgets and had impaired functionality, and only 12 percent of the 3682 projects in 365 countries surveyed were on time and on budget at the time of the survey.

Some of the reasons cited why benefits are not been realised are:

- The implementation of technology is heavily biased towards technology and lacks human and humane attention (Charlton, 2001)

- The process of implementing innovation organisational change has been "too linear and rationalistic" and seen as a single event (Carlopio, 1998, p. 7), rather than an evolving process.

- Many people seem to assume that change, or the adoption of an innovation, is a static event. Organisational change is a social process taking place over a period of time during

Requests for copies should be addressed to: E Harris, Department of Human Resource Management, RAU University, PO Box 524, Auckland Park, 2006 which people and systems must undergo significant change, learning, adaptation and growth (Chowdhury, 1999).

This research attempts to determine why users are not fully adopting technology, which results in companies not realizing the benefits of their ICT investment. This research journal covers the following; the opinions of other researchers regarding innovative technology adoption, the research design, the research findings, discussion of findings and further research and conclusions.

Change is a process, not an event

Traditional ways of thinking about technological change have their roots in Lewin's three-stage organisational transition model of "unfreezing", "change," and "refreezing" (Ottoway, 1983, p. 366)

Unfreezing - is about making people within an organisation ready for change by making them aware of the need for change and dissatisfied with the existing ways of working. It is about creating the readiness for change among the workforce at al levels from senior managers downwards. According to Bux (2002), change is a difficult experience for both organisations and their employees when adopting change.

Moving - is the implementation of the needed changes through the selected range of levers and mechanisms.

Refreezing - involves embedding the changes throughout the organisation to ensure members do not relapse into old patterns and behaviour.

According to Lewin's model, the organisation prepares for change, implements the change, and then strives to regain stability a soon as possible. The change is treated as an event with a specified period.

This may have been appropriate for organisations that were relatively stable and bounded and whose functionality was sufficiently fixed to allow for detailed specification. Today, however, given more turbulent, flexible, and uncertain 
organisational environmental conditions, such a model is becoming less appropriate. In order to manage current levels of change it is required that our current way of thinking about change must be unprecedented, uncertain and open-ended to accommodate the complex and flexible nature of the technologies and organisational initiatives involved (Anderson \& Anderson, 2001; Orlikowski \& Hafman, 1997).

\section{The Individual Process of Change}

Individuals like organisations also undergo a transition, which is the gradual, psychological reorientation process that takes place within people in order to change. According to Bridges (1999, p. 10) individuals move through three phases of transition; ending, neutral zone and new beginning. These three phases described by Bridges are:

- Ending, when we disengage from old ways of doing things and let go of who we were in the old situation;

- Neutral Zone, when we find ourselves in a confusing in between state, when we are not who and where we were, but not yet who and where we are going to be;

- New Beginning, when we grow familiar with and accept (although not necessarily) the new reality change brings.

According to Anderson and Anderson (2001) organisational change managers have in the past managed the transition in organisations from the current to the future state by applying the Lewin's model to organisational transition and Bridges' model to personal transition, see Figure 1.

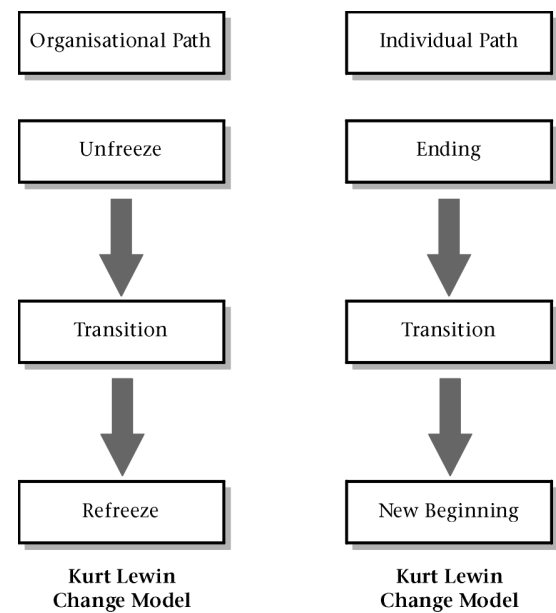

Figure 1: Organisational \& individual change process Kurt Lewin

Anderson and Anderson (2001) also indicate that there are three types of change occurring in organisations, each requiring different leadership strategies. Figure 2 graphically portrays the three types of change; development, transitional and transformational change.

Change management supports two of these types, developmental and transitional change. However it does not suffice for today's breed of complex change transformation, which integrated technology innovation requires. According to Anderson and Anderson (2001) the implementation of "integrated technology innovation" requires transformational change. Transformation is unique in two critical ways. First, the future is unknown at the start of the change process and can only be created by forging ahead with the intent to discover it. Without having a clear goal to manage to, leaders are forced to proceed into the unknown, dependent on broader sources of information and support to formulate a new future and put it into place. Because the future state is not clear at the beginning, the process for getting there cannot be clear either. A time-bound predetermined plan, which most technology implementation follow, is therefore not possible (Carlopio, 1998, p. 14). Since the change process cannot be "managed" a new way of leading is needed.
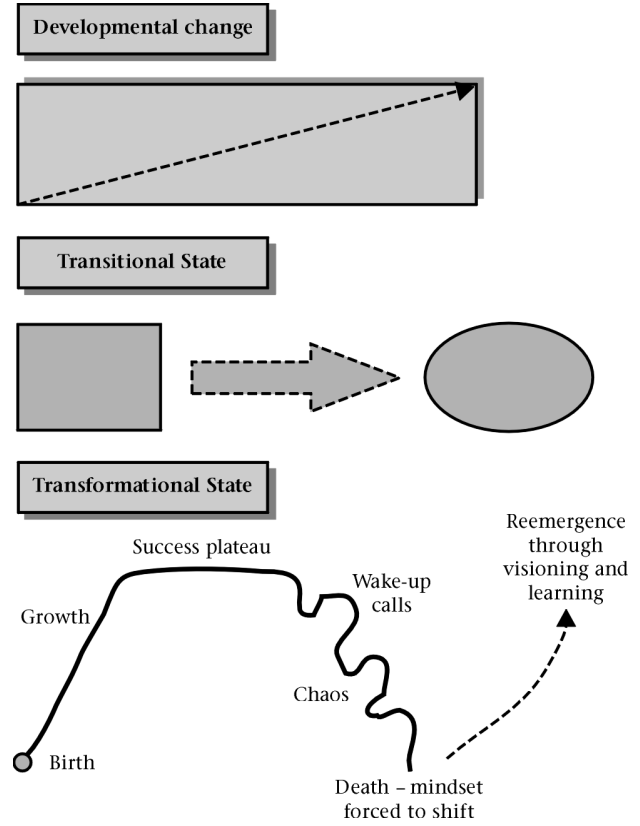

Figure 2: Three Types of Change

Secondly, the future state is so radically different than the current state that a shift of mindset is required to invent it, let alone implement and sustain it. This fact triggers enormous human and cultural impacts. Leaders and employees alike must transform their mindsets, behaviour and ways of working together. This strategy for the change must therefore focus on how to accomplish organisational as well as personal change across the organisation.

According to Anderson and Anderson (2001, p. 42) these two attributes of transformation make both the process and the human dynamics much more complex, unpredictable and uncontrollable than in either developmental or transitional change. In developmental and transitional change leadership typically engage in very little strategic thinking about how to handle the change. Instead they delegate to lower level change mangers that immediately begin implementing planning using traditional project management or change management approaches. In transformational change leaders themselves must be involved in putting together an integrated change strategy (Anderson \& Anderson, 2001, p.43) which includes; 1) correctly positioning the effort within all of the organisational priorities, 2) identify the most catalytic levers for mobilising action toward the future state, 3) set up appropriate participation by all stakeholders in the emergent design of the future and its implementation, 4) clarifies comprehensive change infrastructures and leadership roles, 5 ) creates effective acceleration strategies and conditions and 6) sets a realistic pace for the change.

Another researcher in 1974, Adamson (Conner, 1992, p. 132) developed the seven phase Transition Curve Model, which was based on the Kubler - Ross, 5-stage model, see Figure 3. This model also illustrates that in order to change, people move through seven different stages in order to change:

Shock, individual initially experience shock when they encounter the need for change and dip in their self-confidence due to the need for them to undertake personal change and do things differently. For example when users in organisations are required to use a new technology. 
Denial, is a stage when individuals try to rationalise the changes as not really involving a significant change for themselves. Individuals try to convince themselves that they do not need to use the new technology. As a result their self-confidence goes back up again, however this denial however prevents them from moving forward. Users deny the fact that they too will need to use the technology innovation.

Awareness incompetence, individuals need to develop recognition of the need for personal change. This awareness is created by discussions with others, presentations regarding the change/technology innovation or recognising that the old ways of doing things no longer works. This realisation also results in a drop in confidence as individuals become aware of their inadequacy to fulfil this new role.

Acceptance, individuals will be able to move forward when they accept the need to let go of the past and let go of the 'old' system, old attitudes and behaviour and adopt new ones.

Testing, identifying and testing out technology innovation and behaviours perhaps as a result of training. As new behaviours start to enable individuals to perform more adequately in their new role, the user's confidence starts to build.

Search for meaning, the individual at this stage assimilates learning from their previous successes and failures in using innovative technology and starts to understand why some behaviours worked and others do not.

Integration is marked by an integration of new behaviours of using the technology innovation into that everyday way of working by individuals. The gap between an individual's perceived ability to perform and the expectations placed on that individual ceases to be.

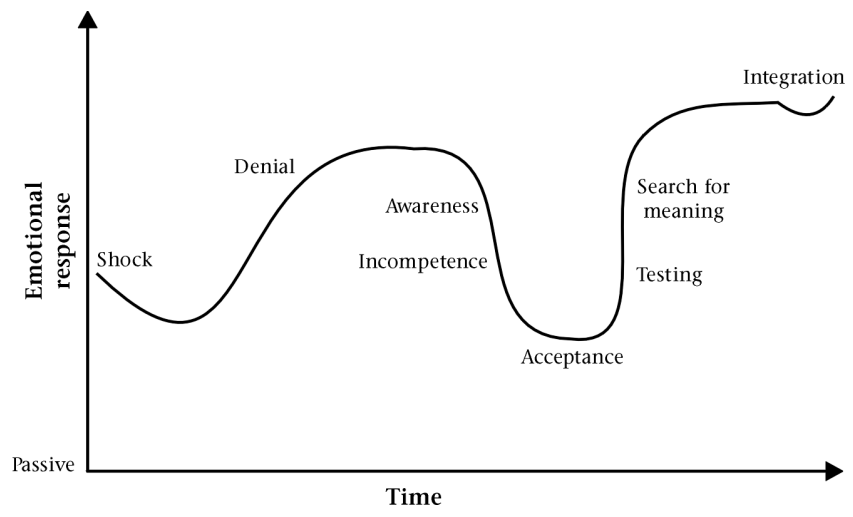

Figure: The transition curve

\section{Change a Highly Personal Experience}

Organisations and individuals not only experience change as a process but also a highly personal process. Hord, Rutherford, Huling-Austin and Hall (1998, p. 32) cited that the world around us is complex and it is therefore not humanly possible to focus on all the many stimuli and conditions that surround us. As a result we place higher priority on some specifics aspects of our world. The way we perceive things is dependent on the unique and multifaceted persons we are as well as the characteristics of the issue, idea, or thing. Our past history, personality dynamics, motivations, needs, feelings, education levels, roles, status, our entire social psycho being in relation to our experiences and knowledge shape how we perceive and, in our minds, contend issues, object or problem at hand. The reason for attention to be focused on a particular issue may be external, influenced by others, by a thing or an idea, or the demands may be internal, coming from within us, or there may be a combination of internal and external stimuli at work.
The composite representation of the feeling, preoccupation, thought, and consideration given to a particular issue or task is called, a concern. Concern, is the mental activity composed of questioning, analysing, and re-analysing, considering alternative actions and reactions, and anticipating consequences, (Hord et al., 1998, p. 33). It is also an aroused state of personal feeling and thought about a demand is, as the individual perceives it. Depending on one's closeness to and involvement with an innovation, one's concerns will be different in type, as well as in intensity. Many types, or levels, or concerns can be experienced concurrently, however, there are normally differential degrees of arousal. For each person, certain demands of the innovation are perceived as being more important than others at a given time. Thus the degree of arousal (intensity) of the different types of concern will vary. Concerns will vary depending on the amount of one's knowledge about and experience with the innovation. According to researchers from the Texas Research and Development Centre, S. M. Hord, W.L. Rutherford and L.L. Huling in 1987 who adapted the Stages of Concern Questionnaire (SoCQ) based on the original concept of G.E. Hall, L. Huling-Austin and L. Dorsett in 1987, there appears to be a predictable pattern to the movement of intensity of concern across types. Table 1 identifies the stages of concern, the description of the concerns and the behavioural indices of the different levels of concern.

TABLE 1

STAGE OF CONCERN, THE STAGE DESCRIPTION AND BEHAVIOUR INDICES

\begin{tabular}{lll}
\hline $\begin{array}{l}\text { Stages of } \\
\text { Concern }\end{array}$ & Description of the Stage & $\begin{array}{l}\text { Behavioural Indices } \\
\text { of Level of User }\end{array}$ \\
\hline $\begin{array}{l}\text { Stage 0: } \\
\text { Non-Use }\end{array}$ & $\begin{array}{l}\text { State in which the individual has } \\
\text { little or no knowledge of the } \\
\text { innovation, no involvement with it } \\
\text { and is doing nothing toward } \\
\text { becoming involved. }\end{array}$ & $\begin{array}{l}\text { No action is being } \\
\text { taken with respect to } \\
\text { the innovation }\end{array}$ \\
\end{tabular}

Stage 1

There is general awareness of the

Orientation learning more about it. The person

The user is seeking out information about the seems not to be worried about self in relation to the innovation. The interest is, in a selfless manner, in substantive aspects of the innovation such as general characteristics, effects, and requirements for use

Stage 2:

Personal

Individual is uncertain about the innovation ands of the innovation, personal adequacy to meet those demands, and his or her role with the reward structure of the organisation. There is also uncertainty about decisionmaking and consideration of the potential conflicts with existing structures or personal commitments Financial or status implication of the program for self and colleagues may also be reflected.

Stage 3: Attention is focused on the

Management processes and tasks of using the Mechanics innovation and the best use of information and resources. Issues related to efficiency, organisation, management, scheduling, and time demands are utmost.

Stage 4:

Impact/ Attention focuses on the innovation's impact on associates

Consequences in the individual's immediate sphere of influence. The focus is on relevance of the innovation for associates; evaluation of associate outcomes, including performance and competencies; and the changes needed to increase associate outcomes
The user is using the change in a poorly and is making userorientated changes

The user is making changes to increase outcomes co-ordinated manner 
Stage 5: The focus is on co-ordination and Collaboration co-operation with others regarding use of the innovation
The user is making deliberate efforts to co-ordinate with others in using the change

Stage 6: Refocusing

The focus is one of exploration of innovation, including the possibility alternatives to the of major changes or replacement established use of the with a more powerful alternative. The individual has definite ideas about alternatives to the proposed or existing form of the innovation

Adapted by Hord, Rutherford, Huling-Austin, and Hall, 1987 based on the original concept of Hall, Wallace and Dossett (1973).

Though the stages of concern are represented sequentially, they frequently overlap. All people are not at the same stage of concern at the same point in time. Change facilitators have to therefore steer a critical mass of people through the stages in order to implement the innovation and bring about organisational change (Veldsman, 2002).

According to Meyers (1994) the basis of organisational change is a desire for different behaviour to lead to better results. Approaches to change tend to focus on the individual or organisational level. At individual level, researchers have examined ways to change behaviours by addressing psychological factors and individual capabilities. Psychological factors such as motivation, attitudes and mental models, explain a person's emotional reaction to change. An individual's level of skill (e.g. technical, interpersonal), capacities (e.g. resilience), and capabilities (e.g. ability to learn) contribute to his or her competence to deal with the consequences of change. A comprehensive change strategy has therefore three equally important components; content, people and process (Sauer and Yetton, 1997).

The content of change includes the new business direction and its subsequent structural, systems products and technology changes. In terms of people, traditional change management focuses on overcoming resistance and increasing communication and training. The focus of this approach is to influence people to change from the outside in. However in terms of transformation change organisation's need to encourage people to chose to change themselves from the inside out to ensure real and lasting change. In order to do this the organisational change strategy has to encourage people to change their mindset and the way in which they behave (Anderson \& Anderson, 2001). Process is how the change will be implemented so that the organisation discovers and accomplishes its business while meeting its people and cultural requirements.

To ensure the sustainability of an innovative technology through users adopting the technology and exploiting the technology innovation the change management strategy must focus on how to accomplish this level of personal change across the organisation, Chowdhury (2001). Hord et al. (1998) indicated that one of the key factors in the change process is the people who will be most affected by the change. Certainly, the innovation itself and the organisation into which it is to be incorporated are important variables, but they are secondary in importance to the people who are the intended innovation users.

Change Is Developmental Growth in Feelings and Skills

As highlighted above people move through stages of concern and feelings in order to master change. This process of mastering the change includes learning and development as depicted in the learning to change ladder (Charlton, 2001). See figure 4 , the Learning to Change Ladder which indicates that we move from the unconscious incompetence to unconscious competence of the new skills. This learning process includes gathering information regarding the change, being taught the new skill, practising the new skill and then using the technology to do their work. This process of learning must be actively facilitated to ensure the user learns how to use the technology innovation and that the skill is reinforced by means of performance measurements to ensure users do not return to the "old" way of carrying out their work.

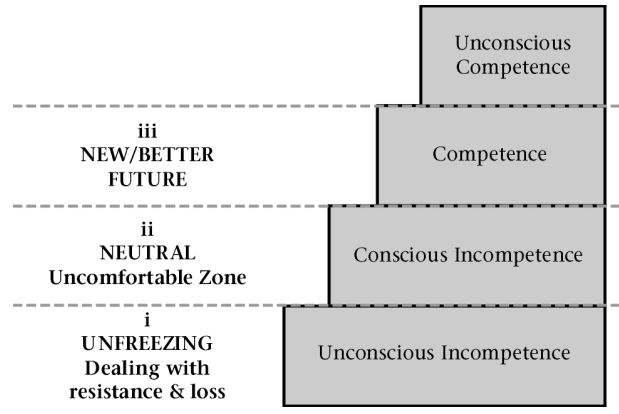

Figure: 4 Learning to change ladder

As previously discussed the studies document by Hord et al. (1998) showed that the stage or stages where concerns are more (and less) intense will vary as the implementation of change progresses. These variations in intensity mark the developmental nature of individual concerns.

While the change typically progresses through the stages in a developmental manner, the progression is not absolute and certainly does not happen to each person in a like manner. Everyone will not move through the stages at the same pace nor have the same intensity of concern at the various stages. For this reason the researcher is of the opinion that this may be one of the reason's which lead to the failure of a number of ICT projects. From the researchers experience of having worked on ICT projects for the last eight years, most IC projects generally allow for between three to ten days for users to be trained how to use the new technology. The training time does not taken into account learners who may be slower than others and allow sufficient time for the user to practice and to develop their confidence in using the new skill.

\section{Hypotheses}

The principal aim of this study was to determine whether there are significant differences between certain characteristics such as; age groups, department and year's experience using the innovative technology, SAP (Systems, Applications and Products in Data Processing) in terms of the different stages of concern users were at, when adopting innovative technology.

In the light of the stated objectives of this study, four hypotheses have been formulated.

$\mathrm{H}_{0} 1$ : There are no differences between the means for users with different levels of experience.

$\mathrm{H}_{0} 2$ : There are no differences between the means for users from different age groups.

$\mathrm{H}_{0} 3$ : There are no differences between the means for users from different departments.

The t-test compares the means of answers to questions relating to each stage by users from the two companies $\mathrm{A}$ and $\mathrm{B}$.

$\mathrm{H}_{0} 4$ : There is no difference between the means for users from different companies $\left(\mu_{\mathrm{A}}-\mu_{\mathrm{B}}=0\right)$ 


\section{RESEARCH DESIGN}

Sample

Two large oil companies were selected in which the researcher had worked in. Both companies had implemented innovation technology, SAP during the last 3 years and the population sample used SAP more than once a day.

The total population of Company A, financial (38 users) and Company B, customer service (32 users) and logistic (22 users) were requested to fill in the questionnaire.

\section{Measuring instrument}

The questionnaire selected to conduct the survey was the States of Concern Questionnaire (SoCQ), Hord et al (1987, p. 5). The aim of the SoC questionnaire is to probe at what stage of concern people are at to use resources and learning interventions which can assist the new user to adopt the technology innovation. The SoC questionnaire is based on the Concerns Based Adoption Model (CBAM), which has the following assumptions regarding change; it is a process, not an event, it is made by individuals first, then organizations, it is a highly personal experience and involves a developmental growth in feelings and skills.

The SoC Questionnaire used was developed to provide a quick - scoring measure of the different stages of concern. It was validated over a three year period, proceeded by ten years of measurement development and research by Frances Fuller and others as they studied the concerns of teachers about teaching, (Hall, Archie \& Rutherford, 1998, p. 9). The resulting SoC Questionnaire was tested for estimates of reliability, internal consistency, validity with several different samples and eleven different innovations. The reason for selecting the SoC questionnaire, is that it is still currently been used by schools, school administrators and researchers in Australia, Belgium, Canada, England, France, Germany, Italy, Japan and The Netherlands to carry out research and facilitate change in schools to adopt innovative technology, (Hord et al., 1998, p. 7). In addition, Theo Veldsman, one of the leading Industrial Psychologists in South Africa refers to the "stages of concern" model in terms of technological innovation and impact on performance in his book, "Into the People Effectiveness Arena" (2002, p. 208).

The SoC Questionnaire which was adopted in its original form consists of an Introductory page, demographics (department, age, qualification, length of use and frequency of use and then the survey questions, 35 items on two pages to which people respond by marking each item on a 7-point Likert scale ( 1 to 7 ) according to how true it is that the item describes a concern felt by the individual at the present time. An additional category, 0 , is provided at the end of the scale to be marked for items that are completely irrelevant to the individual.

\section{Procedure}

The SoC Questionnaire was conducted with the selected sample of users in the following manner:

- A briefing was held with each department manager and employees to highlight the aim of the survey and confidentiality of the employee's responses.

- Employees were then asked to fill out the SoC Questionnaire voluntary and to return the questionnaire in a sealed envelope to the survey administrator. Employees who however wanted to receive feedback in terms of the stage of concern they were at and wanted to know what initiatives were required to move to the next stage could fill their name in.
Statistical analysis of the data

STATCON at RAU did the statistical analysis of the data, which included:

- Calculating the relative intensity of answers to determine to what extent users felt the different stages applied to them. The possible answers are on a scale of 0 (statement considered irrelevant) to 7 (agree completely with statement).

- Conducting correlations between the different stages to see whether a linear progression takes place from stage 1-6.

- Carrying out the ANOVAs and t-tests to determine the differences between the groups of respondents in terms of age, year's experience using the innovative technology (SAP), department and company.

\section{RESULTS}

The results of the study are reported first in terms of biographic and demographic characteristics and then of the analysis. Although the questionnaire was voluntary a good response rate of $80 \%$ was achieved. Table 2 , shows that there were 25 respondents for Company A and 42 respondents for Company $\mathrm{B}$.

TABLE 2

RESPONDENTS PER COMPANY

\begin{tabular}{lcc}
\hline & \multicolumn{2}{c}{ Company } \\
\hline Count & $\%$ \\
\hline Company A & 25 & $37,3 \%$ \\
\hline
\end{tabular}

Table 3, shows that from Company A, 25 respondents were received from the Finance Department and Company B 22 respondents from the Customer Service Department and 20 respondents from the Logistics Department.

TABLE 3

RESPONDENTS PER DEPARTMENT

\begin{tabular}{llcc}
\hline & & \multicolumn{2}{c}{ Department } \\
\hline Company A & Finance & Count & $\%$ \\
Company B & Customer Service Centre & 22 & $37,3 \%$ \\
& Logistics Support Analysts & 20 & $32,8 \%$ \\
\hline
\end{tabular}

Table 4 , presents the age of the respondents, 16 respondents between the ages 18-25 years, 21 respondents between 26-35 years old, 15 respondents between ages 36-45 years and 15 respondents between 46 and above years old. The age of the respondents are evenly spread within the age categories used.

TABLE 4

NUMBER OF RESPONDENTS PER AGE CATEGORY

\begin{tabular}{lcc}
\hline & \multicolumn{2}{c}{ Age } \\
\hline Years & Count & $\%$ \\
$18-25$ & 17 & $24,3 \%$ \\
$26-35$ & 21 & $31,8 \%$ \\
$36-45$ & 14 & $21,2 \%$ \\
$46+$ & 15 & $22,7 \%$ \\
\hline
\end{tabular}


Table 5, indicates the respondent's length of period in using the innovative technology (SAP). Five respondents have between 0 3 months experience, three respondents between 4 to 6 months experience, 12 respondents with 6 months to 1 year experience, 28 respondents between 2 to 5 years experience and 19 respondents with 6 to 10 years experience. Most of the respondents have been using the innovative technology for a number of years.

TABLE 5

RESPONDENTS LEVEL OF SAP EXPERIENCE

\begin{tabular}{lcc}
\hline & \multicolumn{2}{c}{ SAP experience } \\
\hline Count & $\%$ \\
\hline 0-3 months & 5 & $7,5 \%$ \\
4-6 months & 3 & $4,5 \%$ \\
6 months - 1 year & 12 & $17,9 \%$ \\
2-5 years & 28 & $41,8 \%$ \\
6-10 years & 19 & $28,4 \%$ \\
\hline
\end{tabular}

Table 6 , indicates how frequently the respondents are using the innovative technology $1,5 \%$ at least once a month, $4.5 \%$ at least once a day and $94 \%$ twice or more times per day. It seems that most respondents use the innovative technology on a daily basis to do their work.

TABLE 6

FREQUENCY AT WHICH RESPONDENTS USE THE INNOVATIVE TECHNOLOGY

\begin{tabular}{lcc}
\hline & \multicolumn{2}{c}{ SAP frequency } \\
\hline Count & $\%$ \\
Once a month & 1 & $1,5 \%$ \\
Twice or more a day & 3 & $4,5 \%$ \\
\hline
\end{tabular}

The statistical results in terms of relative intensity of answers per stage were calculated and are represented graphically in Figure 5. This shows that the respondents feel that stages 1-2 (Information/Personal) and 4-5 (Consequence/Collaboration) are applicable to them, with users most in agreement with stage 5 (Collaboration). The sample population is split between respondents seeking information and concerned about the impact of technology on them personally whilst on the other hand the other group has moved past their own personal concerns and are concerned about the impact of the technology on others. As most of the users have been using the innovation for a number of years the researcher expected that a large sample of users would have reached a high stage of technology adoption, which in this instance is stage 5 . In addition, lessons learnt from workshops conducted at both Companies A and B have indicated that a high level of co-operation between users and the users understanding of the impact of what they do in the system leads to a higher level of user accuracy and users carrying out actions in the system, timorously.

In terms of the linear progress, Figure 6 shows that the strongest correlation is between stages 1 and 5 (Information/ Collaboration), 4 and 5 (Consequences/Collaboration). The correlation between 4 and 5 was expected according to the model developed by Hord et al. (1998), which indicated this progression. The correlation between 1 and 5 however was not expected. Stage 1 relates to gathering information regarding the technology innovation and stage 5, collaborating to manage the concerns of the technology innovation. The researcher is of the opinion that perhaps the reason for this is that at both stages indicate a desire to gather more information in terms of stage 1 , how the technology will impact the person personally and stage 5 , how the technology will impact others in an attempt to assimilate the new technology.

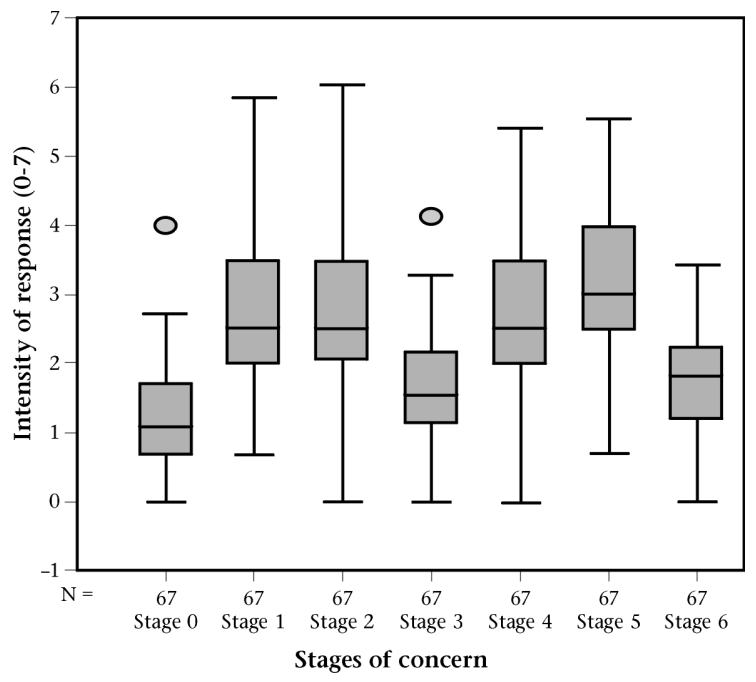

Figure 5: Relative intensity of responses to the different questions

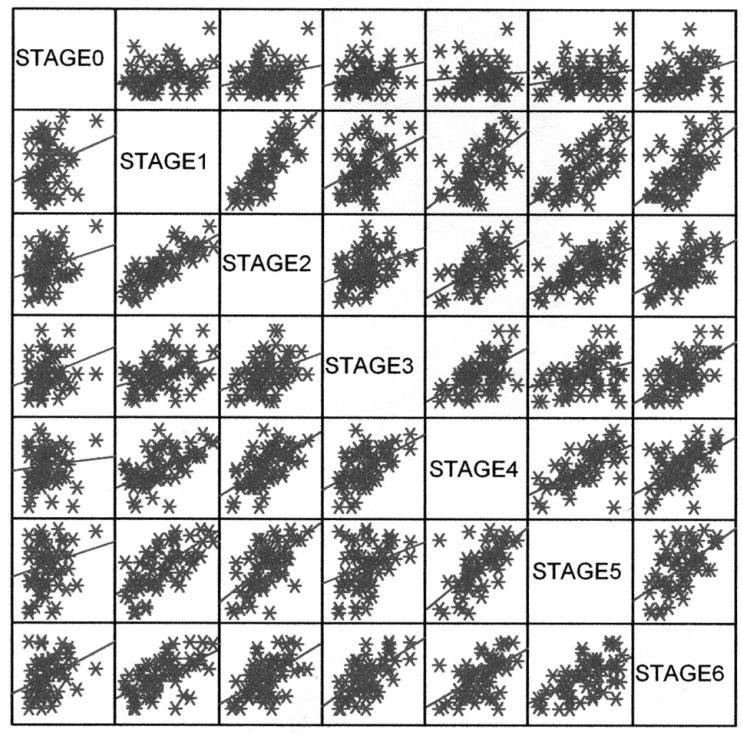

Figure 6: Correlation between stages

The ANOVA tests carried out presents a comparison of the means of the description characteristics, age, length of use and department the users operates in. Where if a $p$ value is less than 0.05 it means there is evidence to infer that there is a difference in at least two of the factors, Keller \& Warrack (2000). Table 7 , the ANOVA results presents no significant difference between respondents groups in terms of the length of using the innovative technology; $0-1$ year, $2-5$ years and 6 to 10 years.

The ANOVA results in terms of age, Table 8 indicates that there is no significant difference between the different age groups, accept a statistically significant difference at a $10 \%$ level at Stage 3 (Management) between the mean of the different age groups, where for ages $18-25$ years the mean is 1.25 , for $26-35$ years the mean is 1.59 , ages $36-35$ has a mean of 2.20 and 46 years and above has a mean of 1.69 . 
TABLE 7

ANOVA ResUlTS - THE LENGTH OF TIME THE USER HAS BEEN USING THE TECHNOLOGY INNOVATION

\begin{tabular}{|c|c|c|c|c|c|c|}
\hline & & $\begin{array}{l}\text { Sum of } \\
\text { Squares }\end{array}$ & df & $\begin{array}{l}\text { Mean } \\
\text { Square }\end{array}$ & F & Sig \\
\hline \multirow[t]{3}{*}{ Stage 0} & Between groups & ,359 & 2 & , 180 & ,275 & ,761 \\
\hline & Within groups & 41,829 & 64 & 654 & & \\
\hline & Total & 42,189 & 66 & & & \\
\hline \multirow[t]{3}{*}{ Stage 1} & Between groups & 1,841 & 2 & ,921 & ,479 & 611 \\
\hline & Within groups & 123,073 & 64 & 1,923 & & \\
\hline & Total & 124,915 & 66 & & & \\
\hline \multirow[t]{3}{*}{ Stage 2} & Between groups & 2,724 & 2 & 1,362 & ,763 & ,471 \\
\hline & Within groups & 114,307 & 64 & 1,786 & & \\
\hline & Total & 117,032 & 66 & & & \\
\hline \multirow[t]{3}{*}{ Stage 3} & Between groups & 3,250 & 2 & 1,625 & 1,615 & ,207 \\
\hline & Within groups & 64,393 & 64 & 1,006 & & \\
\hline & Total & 67,643 & 66 & & & \\
\hline \multirow[t]{3}{*}{ Stage 4} & Between groups & ,061 & 2 & 031 & 020 & ,981 \\
\hline & Within groups & 99,995 & 64 & 1,562 & & \\
\hline & Total & 100,056 & 66 & & & \\
\hline \multirow[t]{3}{*}{ Stage 5} & Between groups & ,510 & 2 & ,255 & , 141 & ,869 \\
\hline & Within groups & 115,897 & 64 & 1,811 & & \\
\hline & Total & 116,407 & 66 & & & \\
\hline \multirow[t]{3}{*}{ Stage 6} & Between groups & ,226 & 2 & ,113 & ,102 & ,903 \\
\hline & Within groups & 71,163 & 64 & 1,112 & & \\
\hline & Total & 71,390 & 66 & & & \\
\hline
\end{tabular}

TABLE 8

ANOVA ReSUlTS - THE RESPONDENT AGE GROUPS

\begin{tabular}{|c|c|c|c|c|c|c|}
\hline & & $\begin{array}{l}\text { Sum of } \\
\text { Squares }\end{array}$ & df & $\begin{array}{c}\text { Mean } \\
\text { Square }\end{array}$ & F & Sig. \\
\hline \multirow[t]{3}{*}{ Stage 0} & Between groups & 2,129 & 3 & ,710 & 1,105 & ,354 \\
\hline & Within groups & 39,810 & 62 & ,642 & & \\
\hline & Total & 41,939 & 65 & & & \\
\hline \multirow[t]{3}{*}{ Stage 1} & Between groups & ,259 & 3 & ,086 & 044 & ,988 \\
\hline & Within groups & 122,027 & 62 & 1,968 & & \\
\hline & Total & 122,287 & 65 & & & \\
\hline \multirow[t]{3}{*}{ Stage 2} & Between groups & 3,448 & 3 & 1,149 & ,631 & ,598 \\
\hline & Within groups & 112,890 & 62 & 1,821 & & \\
\hline & Total & 116,338 & 65 & & & \\
\hline \multirow[t]{3}{*}{ Stage 3} & Between groups & 6,890 & 3 & 2,297 & 2,406 & ,076 \\
\hline & Within groups & 59,178 & 62 & ,955 & & \\
\hline & Total & 66,078 & 65 & & & \\
\hline \multirow[t]{3}{*}{ Stage 4} & Between groups & 6,181 & 3 & 2,060 & 1,378 & ,258 \\
\hline & Within groups & 92,710 & 62 & 1,495 & & \\
\hline & Total & 98,890 & 65 & & & \\
\hline \multirow[t]{3}{*}{ Stage 5} & Between groups & 3,931 & 3 & 1,310 & ,745 &, 529 \\
\hline & Within groups & 109,010 & 62 & 1,758 & & \\
\hline & Total & 112,941 & 65 & & & \\
\hline \multirow[t]{3}{*}{ Stage 6} & Between groups & ,728 & 3 & ,243 & ,218 & ,883 \\
\hline & Within groups & 68,950 & 62 & 1,112 & & \\
\hline & Total & 69,678 & 65 & & & \\
\hline
\end{tabular}

The ANOVA results relating to the department the respondents are operating in, Table 9 indicates that there is no significant difference between respondents operating in different departments except in terms of stage 3 (management), where the mean for the Finance department is, 1.93 for the Customer Service Centre it is, 1.19 and Logistics, 1.78. Customer Service Centre has a lower mean than the Finance and Logistics departments. The researcher is of the opinion that the reason for this may be that the Customer Service Centre staff have strong management who take care of managing the activities of staff in terms of using the technology innovation compared to the Finance and Logistics departments, whose staff are responsible for managing their own workload and use of the innovative technology.

TABLE 9

ANOVA Results - DepartMent

\begin{tabular}{|c|c|c|c|c|c|c|}
\hline & & $\begin{array}{l}\text { Sum of } \\
\text { Squares }\end{array}$ & df & $\begin{array}{c}\text { Mean } \\
\text { Square }\end{array}$ & $\mathrm{F}$ & Sig. \\
\hline \multirow[t]{3}{*}{ Stage 0} & Between groups & ,757 & 2 & ,379 &, 585 &, 560 \\
\hline & Within groups & 41,431 & 64 & 647 & & \\
\hline & Total & 42,189 & 66 & & & \\
\hline \multirow[t]{3}{*}{ Stage 1} & Between groups & 2,046 & 2 & 1,023 & ,533 & ,589 \\
\hline & Within groups & 122,869 & 64 & 1,920 & & \\
\hline & Total & 124,915 & 66 & & & \\
\hline \multirow[t]{3}{*}{ Stage 2} & Between groups & ,665 & 2 & ,332 & ,183 & ,833 \\
\hline & Within groups & 116,367 & 64 & 1,818 & & \\
\hline & Total & 117,032 & 66 & & & \\
\hline \multirow[t]{3}{*}{ Stage 3} & Between groups & 6,902 & 2 & 3,451 & 3,636 & ,032 \\
\hline & Within groups & 60,741 & 64 & ,949 & & \\
\hline & Total & 67,643 & 66 & & & \\
\hline \multirow[t]{3}{*}{ Stage 4} & Between groups & 5,604 & 2 & 2,802 & 1,899 & 158 \\
\hline & Within groups & 94,452 & 64 & 1,476 & & \\
\hline & Total & 100,056 & 66 & & & \\
\hline \multirow[t]{3}{*}{ Stage 5} & Between groups & 1,084 & 2 &, 542 & 301 & ,741 \\
\hline & Within groups & 115,323 & 64 & 1,802 & & \\
\hline & Total & 116,407 & 66 & & & \\
\hline \multirow[t]{3}{*}{ Stage 6} & Between groups & ,963 & 2 & ,481 & ,437 & 648 \\
\hline & Within groups & 70,427 & 64 & 1,100 & & \\
\hline & Total & 71,390 & 66 & & & \\
\hline
\end{tabular}

A t-test was done to compare the mean of answers to questions relating to different stages for users from different companies. T-tests are done where the variance of a population is unknown. At each stage of concern, two t-tests were done; one assuming that the population variances are equal, and one not assuming equal population variances. In both cases, the only statistically significant differences emerged at Stage 3 (Management).

\section{DISCUSSION}

The principal aim of this study was to determine whether various defined user characteristics such as age, department and length of using the innovative technology influenced users at different stages of concern when adopting innovative technology.

According to the statistical analysis respondents were found to have reached different stages of concern in terms of technology adoption. This supports the assumptions of the CBAM developed by Ford et al. (1998, p. 33) that users go through different stages of concern whilst adopting technology.

Conner (1992), a change specialist, also identified that people need to move through stages of change commitment (preparation, acceptance and commitment) in order to bring about major change i.e. innovative technology adoption. 
In terms of the null hypothesis $\mathrm{H}_{0} 1$, no significant difference was found. In terms of the $\mathrm{H}_{0} 2$ no significant difference was found accept a statistically significant difference at a 10\% level at Stage 3 (Management). In terms of the H03 there were no significant differences with the exception of 1 , stage 3 relating to Customer Services. Therefore, with the exception of stage 3 , all the $p$ values were $>0,05$ which implies that the null hypotheses is not rejected and therefore the stage of adoption is not dependent on user characteristics investigated. This supports the assumption of the CBAM developed by Hord et al. (1998), that individuals are different and that people do not behave collectively. Change is a highly personal experience and therefore each individual reacts differently to change. This is also supported by Veldsman (2002) who believes that people conceive, convey, respond to and modifies ideas through and within their interpretative framework, which is very individualistic.

Considering the amount of time and money companies spend on implementing new technology, determining underlying reasons for failing to reach the full potential of these technologies is a crucial exercise. This study shows a way in which the reasons for employees struggling to adopt a new technology can be investigated by using the SoC Questionnaire. The results of the questionnaire will indicate what type of interventions need to be implemented to enable the user to move towards the next stage of concern.

A couple of questions and suggestions emerged. Firstly, it is interesting that the only statistically significant differences between users were found at stage 3 (Management). The reasons for this warrants further investigation. It may be that the trust users have in their direct management plays a crucial role in their trusting the new technology. Secondly, because users were from different departments in the different companies, it is difficult to determine whether differences are due to differences between departments or company. For future studies, it is suggested that surveys be conducted in different companies and involve people from similar departments to enhance the conclusions drawn from the results. Thirdly, the options for users to indicate the frequency of use of the new technology was limited, with $94 \%$ indicating that they use the new technology twice or more per day. For future studies, a greater choice in frequency indication is suggested, which could make the influence of this aspect easier to determine.

The researcher suggests that a survey such as this one should be a standard tool used when implementing new technology. However, the SoC questionnaire should be modified to better reflect the South African circumstances and problems specific to implementation of ICT systems.
A further suggestion based on the aim of the SoC questionnaire is to carry out the SoC questionnaire on a sample of users who are involved in implementing technology innovation. Design interventions based on the results of the questionnaire to assist users move to the next level of concern. Then to re-test the group of users a month after the interventions have been implemented to see whether different results are achieved.

\section{REFERENCES}

Anderson, L.A. \& Anderson, D. (2001). Awake at the wheel: moving beyond change management to conscious change leadership. OD Practitioner, 33 (3).

Bridges, W. (1999). Transition: the crucible of creativity. HRM Magazine, April 1999.

Carlopio, J. (1998). Implementation: making workplace innovation and technical change happen. Australia: McGraw-Hill.

Charlton, G. (2001). Human habits of highly effective organisations. Pretoria: Van Schaik.

Chowdhury, S. (1999). Management 21C: someday we'll all manage this way. London: Prentice Hall.

Conner, D.R. (1992). Managing at the speed of change: how resilient managers succeed and prosper where others fail. New York: Random House.

Hall, G.E. (1979). The Concerns - based Approach to Facilitating Change. Educational Horizons, 57 (4).

Hall, G.E., Archie, A. G. \& Rutherford, A.L. (1998). Measuring stages of concern about the innovation. Austin, Tex.: South west Educational Development Laboratory.

Hord, S.M. Rutherford, W.L., Huling-Austin, L. \& Hall, G.E. (1998). Taking charge of change. Austin, Tex.: Southwest Educational Development Laboratory.

Keller, G. \& Warrack, B. (2000). Statistics for management and economics. $5^{\text {th }}$ edition. London: Duxbury.

Meyers, P.S. (1994). The theory and practice of managing organisational change. Working Paper from Ernst \& Young Centre for Business Innovation.

Orlikowski, W.J. \& Hafman, J.D. (1997). An Improvisational Model for Change Management: The case of Groupware Technologies, Sloan Management Review, Winter 1997, 38 (2).

Ottoway, R.N. (1983). The Change Agent: A Taxonomy in relation to the change process. Human Relations, 36 (4), 361-392.

Sauer, C. \& Yetton, P.W. \& Associates (1997). Steps to the future: fresh thinking on the management of IT-based organization change. San Francisco: Jossey-Bass.

Veldsman, T. (2002). Into the people effectiveness arena. navigating between chaos and order. Randburg: Knowledge Resources. 